\title{
The Financial Aspects of Islamic Education (An Idea to Improve the Quality of Islamic Education in Islamic Boarding Schools)
}

\author{
Abd Mukti', Yusnaili Budianti' ${ }^{1}$ \& Hamdani ${ }^{2}$ \\ 1Postgraduate State Islamic University (UIN) North Sumatra, Medan, Indonesia \\ 2State Islamic University (UIN) North Sumatra, Medan, Indonesia \\ h56294180@gmail.com \\ *Corresponding Author: h56294180@gmail.com
}

Received:72 September 2020

Revised: 10 October 2020

Accepted: 13 November 2020

\begin{abstract}
Funding for education in Islam basically focuses on distributing education costs and burdens that must be borne by the community. Things that need to be considered in education financing are the amount of money that must be spent and where the source of the money is obtained. Thus, based on the source, the cost of education is obtained from the cost of education that comes from the government, the community, and the Baitul Mal. The main obstacle in financing Islamic education is due to limited sources of funds, low support for the community. In this case the thought about the source of education costs, at least the education providers must have planned it in detail because if the implementation process only depends on certain parties, in this case, the education providers are not serious in developing it. All these aspects are the concern of Pesantren in providing education to students, thus the educational aspect becomes part of the aspect of assessment that is very important in learning. The right attitude to respond to today's developments is expressed by the values of moral education developed through management functions to improve the quality of Islamic education in Islamic boarding schools. By implementing it in formal education, Pesantren education, informal education, and non-formal education, it will produce spiritual values, ethical honesty values, and tolerance values. Based on this view, the program implemented felt by all Pesantren residents through a good financial system.
\end{abstract}

Keywords: financial aspects; islamic education;

\section{Introduction}

Education is one of the essential qualities for humans because human education recognizes various concepts for the sustainability of life that it aspires to. Education is an agent of change by transforming values. So education is a valuable asset that needs to be preserved in order to be sustainable. The continuity of activities in education is strongly influenced by various factors and the most essential factor is the cost factor which is important for the survival of an educational institution. The problem of the high cost of higher education is felt by the community. Moreover, the desire that the services provided by education is always a problem that has not been achieved for its satisfaction. Throughout history, financial education has long been discussed and solutions sought so that quality education can be achieved.

Historically, Muslims have understood well about the need for large and organized financing to build and manage quality and quality educational institutions. As an example, Nizham Al-Mulk issued an enormous expenditure budget to finance education so that education can run well. The costs incurred as much as 600,000 dinars or more than 100 trillion each year with all madrasas being cared for by the state and this cost is not a small cost (Yunus, 1992: 36). Most of the education problems faced by the nation in recent times are related to 1) management system based on regional autonomy, 2) waste of budget, 3) unequal education infrastructure, 4) teachers, 5) expansion and distribution of education, 6) quality, 7) relevancy, 8) budget management, 9) management of higher education institutions, 10) management of higher education (Gaffara, 2009: 2). Regarding education equity, it is defined as an equalization in obtaining an education. This means that education providers must find alternative sources of financing education. 


\section{Discussion}

\subsection{Background of the emergence of Islamic education financial problem}

Islam in providing education, Funding is needed in its implementation and the State is responsible for it. This means education provides free education for its people. In Islam, the government is obliged to guarantee every citizen the three basic needs of society, namely education, health, and security. About the affirmation of the rules on education, it's refers that when people are taken prisoner during the Badar war, some of the prisoners who canno Mubarakfuri, 2009: 65).

Islam teaches to always make morals a part of life in life, while the essence of faith and good deeds is morals (Syukur, 2010: 67). This explains that Islam cannot be separated from morals and the reflection of faith is morals. Morals are important for the children of the nation's generation, morals have an important influence in the life of the nation and state. So whether or not it is resilient, its sustainability, misery or welfare of a nation depends on the morals of its inhabitants. To achieve these noble morals, education is needed here. So, if moral education continues to be planted from birth to adulthood, it is possible that a generation that has morals will grow. Cultivation of morals is given gradually and runs continuously until good deeds are embedded in the child's soul. This means that educational institutions are a strategic place in moral education. More than that, Islamic tertiary institutions in particular are institutions for creating generations that provide change in society with moral values

During the time of the Caliph Umar and Uthman, teachers, muezzins, and congregational prayer priests were given a salary from the income of the Baitul Mal. Based on Islamic history, the policies carried out by the caliphs provided free educational services for Muslims. Starting in the IV century $\mathrm{H}$, the caliphs built various universities with various facilities and facilities and adequate libraries. The tertiary institution that was established was equipped with an auditorium (Diwan), dormitories, and housing for educators and scholars. Among the most important colleges that were founded were the Nizhamiyah madrasah and the AlMustanshiriyah Madrasah in Baghdad, the Al-Nuriyah Madrasah in Damascus, and the An-Nashiriyah Madrasah in Cairo. This gives an idea that education is rounded at that time, of course, the financing was very well organized (Khalid, 1994: 22).

Even though education is provided by the state for free, the state does not prohibit every citizen from giving his wealth for education. especially those who are rich, to participate in education including in the form of mandated Waqaf (Qahaf, 2005: 45). Based on this understanding, historically education financing has been implemented. Education is the object of social policy because Islamic education which is carried out contributes to both the economic development and the morals of the nation's generation. So education can be useful for individuals and the general public. It can be concluded that education will deliver a nation towards the welfare of a nation so that if a nation fails to develop the nation, it will give rise to various problems for the nation.

During the reign of the Umayyads in new areas where some of the people did not understand Arabic. So the development of educational institutions is the main goal so that the government area can understand Islam. Meanwhile, the funding of these educational institutions is very dependent on the government as the initiator. During the Abbasid era, many educational institutions appeared in the form of the Jami 'Mosque which functioned as a place for various matters of interest regarding the state and religion. In this Jami 'mosque, there are many halaqah-halaqah places of study for people led by a sheikh appointed by the Islamic government. Operational financing in the mosque is fully borne by the government (Syalabi, 1973: 34). So in this case, it is very clear that the cost of education is very large, the costs are allocated to establish and maintain educational institutions, provide large scholarships for students, pensions, and rations given to students who are entitled to receive them.

\subsection{Sources of Islamic Education Financing}

The existence of social awareness is very necessary to build social activities, including in the field of education. As previously explained, during the time of Khulafaur Rasyidin and Muslim leaders had very great attention to education and science. They have done many things in the development of education by establishing and supporting various means of supporting science and education. One of the sources of education financing is from the government providing education. Where the government is obliged to organize education so that the continuity of Islamic education runs well. The advancement of a national civilization if education is a priority for the country itself. Likewise, in education Islam itself, a source of financing obtained from the state.

Another source of education funding is waqaf, the form of worship in Islam is related to property whose rewards continue to flow as long as others use it. Waqaf is one of the sources of well-organized education funding. The initiator of waqaf as a source of education funding was the Caliph Almakmun, who 
suggested as the initiator. Therefore, it is natural that education at that time advanced because the role of waqaf was very helpful in the implementation of education (Qahaf, 2005: 34).

Based on the description above provides information that waqaf has long been used as a source of financing for Islamic education. The passage of time has developed in various forms, one of which is the tendency of waqaf to pay in cash (money). The technique used is cash Waqaf, namely by making the money as business capital, then the profits obtained used for Waqaf. As was done at the Alazhar higher education institution in Egypt, the process of educational activities that the institution runs is using waqaf funds. The Alazhar Institute manages a company on the Suez Canal whose profits used for educational purposes. Therefore, with productive Waqaf is very appropriate to use as a source of education funding and histories have provided concrete examples of its implementation.

Furthermore, the source of financing for Islamic education is zakat. Zakat is an obligation for every individual who owns assets that have reached the Nisab. Zakat is specific in distribution, namely for the poor, zakat managers, converts, ibn sabil, fisabilillah, and people in debt. The opportunity for the emergence of the use of zakat as a source of financing for Islamic education by interpreting the recipient of zakat further by looking for gaps in the parties that can be used as a source of education funding. Among them are opportunities through the needy, poor, and fisabilillah groups. Al Qardhawi explains in more detail the meaning of fisabilillah and that assumed as into jihad, in general understood that jihad is the defined as a pen and tongue interpreted from a sword or arrow. It will be further explained that jihad can be interpreted in the form of thoughts, education, and social, economic, political (Shihab, 2004: 1998).

The concept of zakat in the context as a source of education costs is included in the category of operational, maintenance, and investment costs that can be obtained from zakat mal by referring to the three groups that receive zakat, namely the needy, the poor, and the fasabalillah. In this way, if the community is able to empower the potential of Muslims with zakat, the problems regarding education financing can be resolved.

Furthermore, the source of education funding comes from donations. The distribution of infaq is different from the administration of zakat, because infaq does not have to give to certain recipients but to anyone. Based on these characteristics of infaq, infaq provides great opportunities for the potential financing of Islamic education. In its implementation, it only needs good regulation and management. In this case, there are at least three infaq management, namely the community, educational institutions and government. If the government manages infaq, the concept is Baitul Mal, if the community then the concept depends on the independence of the community in managing the infaq. If an educational institution manages it, it depends on how the school builds communication with the parents, either directly or indirectly.

Apart from zakat, Waqaf, and infaq. Which are sources of financing for Islamic education, there is still something else that can be used as a source of education financing, namely sadaqah. The concept of sadaqah is not limited to its giving in material form, but also in the form of services that can be used by others. Sadaqah is the same as infaq, which is not bound in its distribution, so the potential of sadaqah is greater as a source of financing for Islamic education. It means that zakat and Waqaf are only certain groups of people who can receive it, while sadaqah can be done by every Muslim, both capable and incapable.

According to the authors' observations, these sources of funding are more dominant in Islamic-based schools. This is because the main source of funding for Islamic education is tuition fees from the students themselves, while government assistance only covers BOS funds; this is the case for private Islamic education madrasahs. As for schools under the auspices of the government or the state, they only think about providing education, because the government covers everything. Especially for private madrasah, if you want to create quality schools, it is not surprising that the tuition fees applied to students are very high because in this case the government still pays less attention to it. Therefore, educational resources are very helpful if managed properly.

\section{Patterns of Islamic Education Financial Management}

When viewed from the history of education financing, there are two patterns in the management of Islamic education finance. The pattern of Islamic education financial management is as follows (Nasution, 2006: 45):

\section{Centralization}

The centralization is the cost of education is has been planned and managed by Government; the management of education costs is no longer an educational institution. Thus, formal educational institutions whose funds regulation by the state, these educational institutions do not have the authority to regulate financial sources. 
The government fulfills all educational needs by the state through the Baitul Mal. Because the existence of educational institutions under the auspices of the government is very dependent on government policies in the field of education.

Education financing, whose source is waqaf as a funding model, is also inseparable from the education management pattern with a centralized system. When waqaf is given for education, often the waqaf giver determines the system for managing the assets of the waqaf given and a clear distribution system of the assets of the waqaf in the waqaf document. In its development, it also does not consider the possible situations and needs of the educational institutions in the future. Moreover, the waqaf giver often determines his heir as the person in charge of managing the waqaf assets in the future.

\section{Decentralization}

second pattern in the management of the Islamic education financial system is a decentralized system, this system is flexible and participatory in implementation compared to the centralized management system. The decentralized system in the management of Islamic education financing, in its implementation, is not only with an approach to financing management patterns of educational institutions which include the real needs of these educational institutions in all their forms of change. In addition, the management approach does not have absolute authority. This decentralized system of management divided into two forms, namely

\section{a. Traditional}

Management system with this traditional pattern, the costs obtained for education are used without clear planning and management. Various forms of educational operational needs will be met when funds come in from educational funding sources, such as from parents, students, philanthropists, and the teachers themselves. When the source of funds is empty, all operational activities and educational needs will be delayed and wait when the source of funds comes again. This decentralization is a traditional style of management and non-formal educational institutions is used. The scholars who teach at home will only meet their educational operational needs using the available tuition fees only or at their own expense, even from additional donations sought.

\section{b. Non-traditional}

The management of education with this non-traditional pattern is a part of the traditional pattern. This nontraditional pattern in managing funds obtained from funding sources that managed by educational institutions with directed management and planning in accordance with the circumstances and conditions of the managing educational institution. For example, the waqaf system is based on the waqaf document that the waqaf giver does not require himself and his successors to manage waqaf that is given to educational institutions.

When viewed from the concept of financing in the field of Islamic education, it provides the concept that in the field of Islamic education the institution as an education provider is a producer of scientific education services and the formation of the character values of a graduate. Thus, Islamic educational institutions will receive input in the form of students who will process through scientific-educational activities and behavior formation. The results of education itself will produce students who will fill the nation's development (Anwar, 2003: 23). Based on this, the organizers must plan and manage education financing carefully, and most importantly financing, must predict a clear source of so that is not hampered implementation. Thus, education will focus more on running education without having to be busy thinking about where the budget is from. Because if the government focuses too much on the current budget, education providers will feel overwhelmed. Based on the concept described above regarding the financing of education in Islam in classical times, this is a solution to the problem must be implemented.

\section{New Initiatives for the Financial Development of Islamic Education in Pesantren}

For some Islamic education institutions in general, the problem that hinders the course of the education process is education funding. Based on research conducted by the Research and Development Center for Religious and Religious Education in 2006 on education financing in madrasas, the results show that the difficulties faced by madrasas regarding the financial management of education is a matter of extracting where the funds are obtained. In this case, raising funds is a major obstacle due to limited sources of funds. The main source of funding for operational education so far is the average tuition fee obtained from students Education costs obtained from student tuition fees are a constant source of education funding, although sometimes these fees are not able to cover the operational costs of the madrasah. The point is that the tuition fees obtained from students must be adjusted to the social conditions of the community in which the madrasah provides education. 
With the presence of the School Operational Assistance (BOS) fund policy, which that given to all schools and madrasah to help with school education financing problems, however, seen from the reality of the field it still cannot cover the required education operational funding. Other sources of funds are obtained from the community in the form of ZIS, but this source of funds is an irregular source and its existence cannot be ascertained. Likewise, the source of funds obtained from the company or local government; however, the school must submit a proposal in the form of a proposal whose answer cannot be ascertained. In this case, there must be a factor in the approach taken by the madrasah organizer with the party providing the funds, so if the madrasah does not have access then has got it.

The problem of education financing is the lack of human resources, where the understanding of financing arrangements and management is still minimal in analyzing the funds obtained. Moreover, the problem faced by education providers in the low support in the community, this is due to the lack of educational institutions involving the community in education management. Moreover, because the community thinks that the government has funded schools, the community thinks that schools should be independent and no longer need assistance in terms of costs. These problems all overwhelm the madrasa in the management of education. The point is that if the costs for operational problems are problematic, it will slow down the movement of progress in education.

When analyzed regarding the problem of financing Islamic education, this is quite a dilemma. Thus it is necessary to plan strategic steps in the solution. The main thing to do is to involve all madrasah components in solving educational problems. Because by involving the school component parties in the implementation of education financing, there will be a solution. So far, it is the practice of education providers, if there is a problem with financing, only a small group of madrasahs takes part in managing it, or even only one party. By involving all madrasah components, there will be a sense of responsibility for all madrasah parties.

When viewed in general about government assistance, it will not be able to meet the problem of financing Islamic education. Therefore, the head of a madrasah, as the driving force behind the running of madrasas, to have expected entrepreneurial skills and managerial and supervisory skills. When viewed from the historical development of Islamic education, the problem of financing is not a problem for educational institutions. If the development is considered, education providers are not consumptive but productive. Therefore, the school must be able to give the community a sense of trust that educational institutions are institutions to make students become skilled human beings. If the community gives a sense of trust, the school creates a separate institution in managing community waqaf for educational institutions or alms, donations, and zakat. Waqaf or ZIS which are managed productively into a business; thus the profits obtained can be used for education without reducing the basic assets that are donated.

The success in managing zakat and during the reign of the Prophet Muhammad waqaf has been proven, Khulafaur Rasyidin, and the Khilafah during the Islamic dynasty. During the reign of Umar din Abdul Azis, a history explained that at that time there were no more people who were eligible to become Musthaq zakat because all of them had been able to become Muzakki so that zakat that should have been for the community was finally given to people in other countries. The success of zakat did not only occur during the golden age of the Islamic dynasty, but at school and in the management of waqaf. In Indonesia, it has also been implemented; specifically in Pesantren.

Thus, if the education party only hopes from the government or student contributions, then the education will run in place. Therefore, in this case education providers can become productive waqaf or productive ZIS as a solution. Moreover, teachers no longer feel that their salary shortages and educational needs are being address. However, when practicing cash waqaf, there are several important concerns (Wadjdy, 2007: 45):

1. What needs to be considering is how the method of collecting funds from waqaf is. The aspect used is certification; this is an advantage of cash waqaf compared to fixed asset waqaf. The advantage lies in determining the amount that can be adjusted to the ability of the candidate wakif.

2. The management of funds that have been collected, this is oriented in the management should be able to provide maximum results as possible. Because it will imply that these funds must be invested in productive endeavors.

3. The proceeds obtained in the form of waqaf are distributed which can be directed to the beneficiaries. What needs to be considered is the purpose of distribution in the form of donations, empowerment, investment in human resources and development.

In education financing generally consists of direct and indirect costs. Direct costs are costs incurred for the purposes of implementing teaching and learning activities or operational costs per day or in a direct period. Meanwhile, indirect costs are expenses that indirectly support the educational process but allow the educational process to occur in schools. In this case the thought about the source of education costs, at least the education provider must have planned it in detail, because if the implementation process only depends 
on certain parties, in this case the education provider is not serious in developing it

Based on the description above, it is clear that the problem is quite a dilemma above, it is necessary to take strategic steps in solving the problems faced by madrasas. Every problem faced by madrasah can at least clarify and provide practical solutions in order to improve the quality of education led. In the opinion of the writer, several things need to be considered. First, the problem of financing is a very sensitive matter. It can bring progress to the institution if it is managed properly. Moreover, it will bring the institution down if the components/parties in the institution do not manage it professionally and are oriented towards improvement, only based on personal interests.

Therefore, all components in educational institutions, in relation to the process of preparing education financing, must be involved. This is done as a manifestation of the principles of openness, togetherness, and responsibility for institutional mandates that must be shared. Good and bad institutions become joint accountability. Second, in relation to the placement of the party's allocation of funds, efforts are made to be able to compile and manage properly, how much budget is there, how the budget is spent or allocated, and how is the reporting system. If there are components in it that do not understand, it is necessary to conduct training on how to prepare a good budget. It could be with budgeting training or other similar things. Third, the principal as the driving force is expected to have entrepreneurial skills and managerial and supervisory skills. Fourth, madrasah should involve the community in budgeting for education funding, through regular meetings or it can be inserted at a school promotion/graduation meeting. This is done as a form of the principle of openness.

Fifth, Islamic educational institutions, in this case madrassas, as institutions based on religion in which there are noble values, are expected to uphold the principles of justice, the principles of trust, honesty, deliberation, openness, discipline, and so on. These principles must be adhered to by all elements of the institution. Thus, it is hoped that there will be a management solution for Islamic education financing, so that a good Islamic education institution will be formed, especially in the issue of education financing.

One of the peculiarities carried out in various activities at Islamic education-based foundations is always to prioritize the principle of togetherness in unity and kinship bonds and friendship. In the Pesantren all communities work together in all activities carried out at the foundation. Students who violate the foundation's rules will take firm action against violations committed by students or teachers. Students who fail to comply with the established rules will be subject to sanctions. Teachers who cannot carry out their duties properly will also be reprimanded for the first time and will be dismissed from the teaching staff if they repeat it. This implementation is a follow-up to planning and organizing is the core activity of educational institutions. Therefore, the office holders must work properly so that the planning targets are achieved. A foundation with all its limitations is able to drive education according to its vision and mission. If all units can carry out their duties properly, the implementation of education at the foundation in the future can be even better than what has been achieved so far. Sincerity and responsibility must always accompany the implementers of education. So based on this a sense of belonging must be owned by education management actors at the foundation. With a sense of love and responsibility, duties can be carried out well, calmly and happily. If everything works well, the quality of Dayah education in the future is expected to be even better.

To implement this, supervision is needed so that every prepared plan runs well. Supervision activities are carried out on two occasions, namely when the activity is carried out and after the activity is carried out. When activity is being done; the form of supervision can be in the form of guidance and direction for the smooth running of activities. Meanwhile, after the activity is completed, the form of supervision is in the form of evaluation (evaluation) whether the activities carried out are in accordance with what is being carried out. If it is not in accordance with what was planned with what was carried out, then it is necessary to take feedback (follow up) about what things can be corrected so that there will be no more mistakes in the next activity. The implementation of these activities is carried out together and there are elements cooperation between all personnel who have been assigned to these activities. The final activity in implementing the modern management function is by controlling (controlling), where in the student admission activity, the leadership of the Islamic boarding school always supervises from the time the activity takes place until the completion of the new student admission activity (santri). The form of supervision carried out is guidance, direction and assessment. Matters that are supervised are related to the entire implementation of activities from the start of the activity to the end of the activity, regarding the material whether the activities that have been carried out are in accordance with the plans and objectives that have been set

Regarding this matter, it is described in the Al Quran as an inspiration for the importance of this supervision QS. Al Infithar 10-13. 
10. In fact, for you there are (angels) who watch over (your work), 11. who are noble (with Allah) and record (your works), 12. they know what you do. 13. Verily those who are much devoted are truly in a heaven full of pleasure.

Based on the above description, it can be understood that supervision is a very important thing to do. Unsupervised policies will not work as intended. In the context of education management at the Darul Amin foundation, supervision has been carried out, supervision is carried out using certain instruments, there is also supervision carried out directly in the field by the rais amam and the highest management of each field. The purpose of this supervision is so that educational activities can run optimally exactly as planned, or at least close to the goal. Educational supervision at the Darul Amin foundation functions as an enforcer of discipline in duty, supervision with attendance makes teachers more disciplined in their duties, so that time can be used properly. Thus the learning target can be achieved every semester before the exam.

Direct field monitoring is carried out on programs that require large budgets. The most important thing in improving the quality of education through management is establishing the right curriculum in formal education, dayah education, and informal campus education that is integrated with spiritual values, honesty and tolerance values in order to build the strength of understanding the correct faith as a foundation in religious life. The goal is to guard against disgraceful acts and to build a strong and correct religious spirit that must be in line with building a morally and civilized society as well as intelligent in faith. Islamic teachings teach peace, and if all of this used as a foundation in implementing ethics and rules of conduct in a foundation, it will lead people to live a peaceful, happy and prosperous life.

Pesantren has an interest in fulfilling various dimensions of community satisfaction, especially students, for the realization of quality student output so that they can make the best contribution in their service for the benefit of society. The self-maturity possessed by the santri includes psychological maturity, as a person who is able to direct himself, encouraging the emergence of psychological needs, namely the desire to be seen and treated by others as a person who directs himself, not directed, forced or manipulated by others. santri are interested parties and are directly influenced by the learning and management of Pesantren managers. This is where the role of management in improving the quality of education in Pesantren through a good financial system. Therefore, the implementation of management functions in Pesantren that cover Pesantren education, formal education, informal education, and formal education is not only focused on students. Therefore, in this case, students and the community of Pesantren education personnel make an important contribution to learning services, management and provision of adequate lecture facilities, guaranteed security and a comfortable life and Pesantren environment for Pesantren residents. Moreover, satisfaction of educational service users is very important for the progress of an educational institution, as for a university, the satisfaction of students as the main service users is a milestone for the sustainability of an educational institution. This is because the satisfaction of the community and students will have an impact on their loyalty to the foundation. So in this case, the quality of the students is not only intellectually but also spiritual and moral so that it gives birth to a complete human being. So the santri as students as social actors interpret their own empirical world independently and differ from one another. Thus, qualitative aspects are prioritized compared to quantitative aspects in understanding a context of knowledge obtained in learning. Especially in Islamic teachings, the goal of Islamic education is to make students as agents of change. The point is that as an ideal student to be part of a good society is to be able to do good both vertically and horizontally. Regarding this, Allah describes this concept in QS. Al Jumah 62: 2 as follows:

He who sent to the illiterate a Rasul among them, who read His verses to them, purified them and taught them the Book and Wisdom (As Sunnah). and Behold, they were in real error before.

Basically, in Islamic education at the operational level, education can be seen in the practices carried out by the Prophet, among others, as written in the verse above. The words purify which the Quraish Shihab explains, that be identified with educating, teaching is nothing but filling the minds of students with knowledge related to the realms of metaphysics and physics. All these aspects are the concern of Pesantren in providing education to students, thus the educational aspect becomes part of the aspect of assessment that is very important in learning. The right attitude to respond to today's developments is expressed by the values of moral education developed through management functions in order to improve the quality of Islamic education in Islamic boarding schools. By implementing it in formal education, Pesantren education, informal education, and non-formal education, it will produce spiritual values, ethical honesty values and tolerance values. Based on this view, the program implemented that be felt by all Pesantren residents through a good financial system. 


\section{Conclusion}

Funding for education in Islam basically focuses on distributing education costs and burdens that must be borne by the community. Things that need to be considered in education financing are the amount of money that must be spent and where the source of the money is obtained. Thus, based on the source, the cost of education is obtained from the cost of education that comes from the government, the community, and the Baitul Mal. The main obstacle in financing Islamic education is due to limited sources of funds, low support for the community. In this case, the thought about the source of education costs, at least the education providers must have planned it in detail, because if the implementation process only depends on certain parties, in this case the education providers are not serious in developing it.

\section{References}

Al Mubarakfuri, Adiwarman. (2009). History of Islamic Economic Thought, Jakarta: IIIT.

Khalid, Abdurrahman Muhammad. (1992). Questions and Answers Regarding the Islamic Movement, Bogor: Pustaka Thariqul Izzah.

Muhammad, Qutb Ibrahim. (2002). Economic Policy of Umar bin Khaththab (As-Siayasah Al-Maliyah Li 'Umar bin Khaththab), trans. Ahmad Syarifuddin Shaleh, Jakarta: PustakaAzzam, 2002.

Nasution, Edwin M and Hasanah U. (2003). Cash Waqaf for Islamic Financial Innovation Opportunities and Challenges in Realizing the Welfare of the People, Jakarta: PSTTI-UI, 2003

Qahaf, Mundzir. (2005). Productive Waqaf Management (Al-Waqaf Al-Islami TathawwuruhuIdaratuhu Tanmiyatuhu), Terj. Muhyiddin Mas Rida, Jakarta: Khalifa.

Syukur, Amin. (2010). Pengantar Studi Islam (Introduction to Islamic Studies), Semarang: Pustaka Nuun.

Yunus, Mahmud. (1992). History of Islamic Education, Jakarta: Hidakarya Agung 